\title{
The Analysis of the Development Background and Strategy of Local Application-oriented Undergraduate
}

\author{
Xiaolong Li \\ Jiangxi Institute of Fashion Technology \\ The City of Nanchang, Jiangxi, Province, China \\ e-mail: 576816683@qq.com
}

\begin{abstract}
With the coming of the massive higher education, the colleges which are suitable to the district development are growing in number gradually. To explore positively the development background of local application-oriented colleges enriched the perceiving to the classification towards the higher education. Analyzing the characters and the problems of local application-oriented colleges provides corresponding strategies for the forward de velopment of local application-oriented colleges.
\end{abstract}

Keywords- higher education institute classification; massive higher education; the application-oriented colleges; strategy; development

\section{INTRODUCTION}

Recent years, there are many areas especially in the development areas of Pearl River Delta which are found to be hard to recruit the suitable employees, which happened often. On the other hand, the education departments are worrying the graduate quantity which is increasing year after year. With the deep reform of higher education, aiming at the great difference and gap between the surplus of college students and the serve deficiency of skilled workers, the top-level design should be done to improve the level of serving the society and the economy, to propel the strategy of strengthening by the person with ability, to ease the situation of the people understanding high technology and to make the talent structure achieve the balance condition. The report in the $18^{\text {th }}$ CPC National Congress has proposed explicitly that the connotative development of higher education must be promoted through the development of modern vocational education. The third Plenary Session of the $18^{\text {th }}$ Central Committee of the Communist Party of China has decided that the education must be reformed comprehensively and the construction of modern vocational system must be accelerateed; the labors and workers must be cultivated to be highly skilled and qualified through deepening the melting of industry and education and the cooperation of colleges and enterprises. Under this situation, the development of local application-oriented colleges has been put on the agenda, which means that some colleges will transform from academic colleges into the local application-oriented colleges. [1] On the $22^{\text {th }}$ of March in 2014, the undersecretary of education department disclosed that more than 600 local colleges would transform into the application-oriented technology and vocational education types in China Development Forum. It was said that more than 22 provinces have started the job of college transforming development. The province in which the author lived in has also started the job of college transforming development in February of 2015, containing ten colleges such as Ceramic Institutes of Jingdezhen, Nanchang aeronautical university, Xinyu college, Yichun College, Jiangxi Institute of Fashion Technology. Therefore, it has important significance to explore the development background and strategy of applicationoriented colleges positively.

\section{THE CONCEPT OF THE LOCAL APPLICATION- ORIENTED COLLEGES}

It is necessary to know about three official classifications towards the higher education institute before understanding the concept of the local application-oriented colleges. Accord to the specification, it can be classified into key university, normal university and higher academic college; According to the subordination, it can be classified into the colleges owned by the certain industry, the colleges owned by the education department directly and local colleges; According to the subject and the nation, it can be classified comprehensive university, science and engineering university, agriculture and forest university, medical university, military university, normal university, financial university, law university, sport university, art university and national university. In the first classification of this kind, local application-oriented colleges belong to the normal university. The famous higher education specialist Pan Maoyuan considered that China's higher education institutes could be classified into 3 basic types: the first type is academic university which means what is usually called comprehensive university or Research University. [2] The level of this kind of university contains bachelor's degree, master's degree and doctor's degree. The second type is application-oriented colleges which can also be called single or multiversity, the single is called college and the multiversity is called university; the third is vocational technology institute, of course, it can also be called single or multiversity. However, according to the research scale, Wu Shulian classified China's institutes into research university, research-teaching university, teaching-research university and teaching university. In this classification, the local application-oriented belonged to the teaching university. Then what's the new built local college? Since 1999, under the background of higher 
education massive, some academic colleges belonging to the local province and city and independent college were merged, recombined and upgraded into normal colleges. The newly built colleges are different from the famous colleges which have a long history. They have unique characters though they are grown up from the academic college and have great importance towards the development of the local society economy. Recent years, the newly built colleges have faced many development predicaments. Therefore, it is very necessary for the transformation of the newly built colleges into the local application-oriented colleges. According to the features, and by the way of the connotation towards teachingresearch university in the paper of Constructing Teachingresearch University----talk about the institute's classification concurrently which was published in Education Research by the professor Liu Xianjun. The concept of the local application-oriented college can be made as follows: give priority to the undergraduate teaching, according to the situation and needs, develop graduate education when it is necessary, the teaching and the research should serve the local mainly, cultivate the talent that the local need, produce the application-oriented fruit that the local need, greatly unfold all kinds of service actives that the society need, form the system serving for the local from all around. The aim of the local applicationoriented college is to cultivate the vocational technology talent who will obtain the bachelor's degree if they finished their study. [3] The students in the local application-oriented college do not only accept the system theory training, buy also master a certain technology which is used to serve the society.

\section{THE DEVELOPMENT BACKGROUND OF THE LOCAL APPLICATION-ORIENTED COLLEGE}

China has met the standards of massive higher education after increase enrollment in 1999. In normal college, the trend is obvious that the college pays attention to the theory, but looks down on the practice, which will lead to some social problems due to its graduates are hard to adapt the needs of the society and the enterprise. Therefore, after the college's transformation from elite education to the massive education, it is necessary for some colleges to adjust their goals of cultivating under the situation of upgrading industrial structure and meeting the students' needs of finding suitable jobs. As it is known, just in this situation, the application-oriented colleges are appearing. [4]

\section{A. The domestic background}

Early in July of 2010, national medium and long-term education reform and development plan (2010-2020) has said that the higher education structure must be deepened again and again and dynamic adjustment system must be built to meet the needs of China and the local economic development. It is a must to optimize the major of the subject, the type of the subject and the hierarchical structure to promote the intersection and combination of the subject. Mainly expand the cultivating scale of application-oriented type, comprehensive type and technical type, which (the top-level design) has started new prologue of the education reform of China. On the $24^{\text {th }}$ february 2014, the executive meeting of the state council has said explicitly that it is a must to guide the transformation of certain normal colleges to the application-oriented colleges. After two days, the state council had convened the executive meeting to discuss the topic that how to accelerate the development of modern vocational education. The meeting had passed the decision of accelerating the development of the vocational education and confirmed the measures to accelerate the development of the modern vocational education. Soon, three documents were opened successively: the decision about accelerating the development of modern vocational education; the planning of modern vocational education system; the education department's guide decision about the transformation development of the local colleges. In the document of the education department's guide decision about the transformation development of the local colleges: in order to implement national medium and long-term education reform and development outline (2010-2020), to accelerate the construction of modern vocational education system, to propel the transformation of the local colleges, to enhance the service ability for the society and the economy, and the whole mentality and the main task of the transformation of the local college must be decided. Three basic principles were emphasized in the whole mentality, the first is to insist pilot and demonstration guidance; the second is to insist need guidance and classification pushing; the third is to strictly insist top-level design and comprehensive development. Besides the three basic principles in the whole mentality, the four basic goal were specified. The first is to construct an array of demonstration application-oriented colleges; the second is to improve the quality of students employment rate in the demonstration college; the third is to advance the service ability of the demonstration college to the key industry and upgrading; the fourth is that the overpass of talents cultivation must be formed on the whole. Especially the twelve measures which are used to ensure the implement of the local application-oriented college provide the ideological foundation and material guarantee for the transformation of newly built colleges to the local application-oriented college.

\section{B. The overseas background}

The local application-oriented college that was being advocated means the application-oriented technology university which rose in European in the 1960s from newly built colleges or through the upgrading of the vocational college.[5] Through the transformation, it has the same status with the research university. The school runningorientation emphasized the major technology mainly and cultivated the technology talent with science review and science ability, later it also expanded gradually the function of taking application-oriented research. A certain department under the education department had made an analysis towards the process of the society and the economy all over the world since the global financial cris is and obtained an important enlightenment that the structure of higher education and the system construction of the vocational education have close relationship with the competition of the country, the development of the substantial economy. The application-oriented colleges in German originated from late in the 1960s. This kind of college hammered at cultivating practice workers 
mastering all kinds of special technology with the senior application-oriented and engineer vocation. The characters of the teaching method contain freedom, closeness, modeling, interesting and practicing. [6] The community college in American insists on the school-running idea of equality and mass, the tuition is cheap, the setting of the course is rich. The goal of this kind of college devotes to the service of the enterprise and the local economy. The short college in Japan has short time in school, generally speaking, only 2 years, some maybe 3 years, such as the medical technology and the nurse major. However, it emphasized the technology training after the students entering the society directly. The city college in England is operated by the social donation. The expenditure is obtained from many organizations. The college builds union and enhances cooperation to contribute the local economy.

\section{THE MAIN CHARACTERS OF THE LOCAL APPLICATION-ORIENTED COLLEGE}

On the cultivation goal, the students work on high technology job under the science theory guide. The local application-oriented college that is being advocated doesn't mean abandoning the learning of theory completely, addicting to practicing model and drill. They must master related basic science theory before they start the related actives.

On the cultivation hierarchy, the paper emphasizes the knowledge, the quality and the ability structure, mainly cultivated 4-year students. It has differences with the traditional 3-year academic colleges though advocating the application-oriented and practice. The students in the local application-oriented college must master some theory knowledge, which will build a bridge and create the space for the students to improve and promote the connecting of technical secondary school, higher vocational education and the major master. It avoids the dead end highway and builds overpass.

On the science research, the local application-oriented college must undertake certain science research, containing application-oriented research and development research. The kind of research has close relation with the local social and economic development.

On the social service, the local application-oriented should adapt to the needs of the local enterprises and run facing to the local.

\section{THE PROBLEM FACED BY THE DEVELOPMENT OF THE LOCAL APPLICATION-ORIENTED COLLEGE.}

The classification system and evaluation criterion are single. For a long time, the college is divided into key university and common university. For example, the 985 and 211 universities belong to key university, others belong to common university. Sometimes, the college is divided into comprehensive university, single-subject university and art university. Under this situation, the local application-oriented college is hard to belong to them. Reasonable classification of institute should be us eful to the cooperation of different types and hierarchy. Here, I'd like to introduce a scheme of classification about the institute (as Table 1). [7] In this form, it can be seen that the status of the local application-oriented college obviously.

As it is known, the evaluation criterion and valuation are single in the traditional college, which emphasizes research. The status in all the colleges and the scale, which is a shortcoming for the application-oriented to obtain the funds from the country.

TABLE I. A SUGGESTIVE SCHEME ABOUT THE TYPE AND HIERARCHY ABOUT THE INSTITUTE

\begin{tabular}{|c|c|c|c|c|c|}
\hline \multicolumn{2}{|c|}{ Elite higher education } & \multicolumn{4}{|c|}{ Massive higher education } \\
\hline institute & $\begin{array}{c}\text { Academic } \\
\text { degree }\end{array}$ & institute & Major degree & institute & $\begin{array}{c}\text { Vocational } \\
\text { degree }\end{array}$ \\
\hline \multirow{3}{*}{$\begin{array}{l}\text { Research } \\
\text { university }\end{array}$} & doctor & \multirow{3}{*}{$\begin{array}{l}\text { Comprehensiv } \\
\text { e university }\end{array}$} & doctor & \multirow{3}{*}{$\begin{array}{l}\text { The application- } \\
\text { oriented college }\end{array}$} & doctor \\
\hline & master & & master & & master \\
\hline & bachelor & & bachelor & & bachelor \\
\hline \multirow{2}{*}{$\begin{array}{l}\text { School of arts } \\
\text { and sciences }\end{array}$} & \multirow{2}{*}{ bachelor } & \multirow{2}{*}{$\begin{array}{l}\text { Professional } \\
\text { college }\end{array}$} & master & \multirow{2}{*}{$\begin{array}{l}\text { Vocational } \\
\text { technology } \\
\text { college }\end{array}$} & bachelor \\
\hline & & & bachelor & & Vice bachelor \\
\hline
\end{tabular}

The great pressure from the rise sharply of vocational college In order to implement the spirit from the decision of striving to develop the vocational education, early January 2006, the education department and the financial department had started the Plan of National Demonstration Vocational Construction, which was called

The 211 project of the vocational college. Due to its advantage, the technical college has occupied in half of the 
institute, which brings great pressure to the local application-oriented college which just is established in recent years. Besides, the quality of the higher education was decreasing due to the massive enrollment since 1999. People missed the elite times with the comparis on to the massive education times. In that time, the college students are unusually the lucky persons loved and praised by everyone. Then what's the valuation of people's impression towards the college students? There are too many college students. Almost everyone on the street is college student, which makes the public look down upon college students. Of course, it is not unfounded. [8] After the time of massive higher education, due to the quality of the staff, the model of cultivating and the source problem of the enrollment students, modern students really have gap with the college students in the elite higher education times. Therefore, after the opening of the scores of the College Entrance Examination, there's a battle going on to struggle the students who obtained high scores in the College Entrance Examination, not less than happened in common colleges. Due to the brand, running scale and the location, the new-established college is inferior to the traditional college.

C. The convergence of the major, the short of the feature. The characters of the local application-oriented college is short of the local and the regional. According to the enrollment data of the college (4 years), almost half new-established colleges enroll students centralizing English major, computer major, art design major, marketing major, international economy and trade, electric information engineer and Chinese language and literature, and the enrollment ration is above the average of other colleges. These majors have no characters and are hardly suitable to the structure of the industry. [9] The students who choose the major are easy to find jobs or lose jobs even they find a job for the moment.

\section{THE DEVELOPMENT STRATEGY OF THE LOCAL APPLICATION-ORIENTED COLLEGE}

\section{A. Make the sounder law and regulation through the macro-control measure.}

Not a radius of no rules, the development of the local application-oriented college needs the guarantee of the law and the regulation. Luckily, two documents have been published, the decision of accelerating develop modern vocational education of the State of the Council; the system planning of the modern vocational education, which took a reassurance to the local application-oriented college. The top-level design has been published, the local colleges should regulate corresponding polices and regulations which are suitable to the situation. Only through the way can the place of the local applicationoriented college of China be as sured.

\section{B. Classify the institute reasonably, ensure the place of the new-established college.}

Just what have been discussed as before, due to the traditional, newly-established college have many limits. What's the most important: the funds, which are less the demonstration vocational college, not mention to the 985 project. Therefore, the education department should enhance the reform of college setting, valuation, allocation and management regulation. Let the local applicationoriented college to explore the modern college system and assure the place of the local application-oriented college.

\section{Change the traditional model of cultivating talent, face the market to highlight the characters.}

Optimize the quality of the staff through the enrollment of excellent people. The famous educator Mei Yiqi said that a college is called college due to its master not due to its building, which is suitable to the local applicationoriented college. [10] The development of the applicationoriented college need more and more staff who are "double-qualified" technical teachers. When they were enrolled, the school should let them stay forever. To the teachers who are anxious for the contribution to education career, it is necessary to keep them stay through the salary, even the policy and the feelings.

It is necessary to assure the goal of cultivation and emphasize the ability of practice. The cultivation of the application-oriented colleges have many differences with the traditional college or comprehensive university. The steady theory knowledge is emphasized in comprehensive university, the students who graduate from the comprehensive university have the chance to work on science research systematically. However, the applicationoriented college students only master some certain theory knowledge, then work on the applied research related to the industrial, which stresses the connection with the career and emphasizes the practice ability.

Promote the cooperation between colleges and enterprises, build more brand effect. Jiangxi Institute of Fashion Technology in which the author works is an application-oriented college with the distinctive characters emphasizing the ability of students' doing. [11] This college emphasizes the cooperation with enterprises, which will produce brand effect for the college. The college has built cooperation relationship with many famous enterprises and companies, for example, the cooperation with the city of Shishi in Fujian Province. Through the cultivation of order teaching, the students obtain amounts of internship opportunities.

\section{REFERENCES}

[1] The Transformation Development Practice and the Policy Research Report on the Local Undergraduate. Nov, 2013

[2] Pan Maoyuan and Dong Liping, "the Discussion about the Classification, Position and Distinctive Development of the Institute". Education Research, vol 2, 2009.

[3] Zoo Xiaoping, "Discuss the Classification Framework of the Institute again” Higher Education Research, vol 5, 2012.

[4] Qi Ping and Zhu Jiayong, "Strategy of Goal Adjustment and Acheievement in Talent Cultivation in Applied Institutions of Higher Learning”. Higher Education Forum, Jun. 2010.No.6.

[5] Liu Xianjun, "construct teaching service university and the discussion to the classification of the institute". Education Research, vol7, 2007.

[6] Chen xiaohu, "the Development Setting, Mission, Ways and Method Choice of Newly-established Application-oriented colleges". China University Teaching, vol 3, 2014.

[7] Liu Yourong, "A Study on the Development of Upgraded Application-oriented-Oriented Undergraduate Collegs", Doctor's Degree,

[8] Zhu Liansheng, Wang Hongmei and Liu Qingqing, “ A Probe into Teaching Reform of Application-oriented-Oriented Universities Based on Guidance of Social Need", Theory and Practice of Education, vol.30,2010. 
[9] Liu Xiaoming, Industry Transformation and Upgrading and the Development of Higher Vocational Undergraduate Education: Transformation of Local Application-oriented-Oriented Undergraduate to Higher Vocational Undergraduate Education as a Solution”. Education Development Research, vol.32012.
[10] Pan Maoyuan, the Theory and Practice Research of the Cultivation in the Application-Oriented Undergraduate. Xiamen University press. Page 142.2012.

[11] Qian Guoying, Education Creation and the Cultivation of the Applied T alent, Zhejiang University Press. Page 273. 2013. 